\title{
KETAATAN MUSLIM INDONESIA TERHADAP PENETAPAN HARI RAYA ANTARA ITSBAT PEMERINTAH DAN IKHBAR ORMAS ISLAM
}

\author{
Nihayatur Rohmah \\ Institut Agama Islam (IAI) Ngawi \\ nihayaturrohmah@yahoo.co.id
}

\section{Abstrak}

The issue of "hisab rukyat" in terms of determining the beginning of the Islamic month often makes a difference. Government efforts through itsbat trial basically are based on efforts to achieve uniformity, benefit and unity of Indonesian Muslims. But in the level of reality, it turns out that each party (read; religio social organizations) issued its own decision. Religion has an influence as a motivation in encouraging individuals to carry out an activity, because actions carried out against the background of religious beliefs are considered to have an element of purity and obedience. This connection will influence someone to do something. Then came the Islamic groups who wanted to compromise with the government and Islamic groups who continued to fight outside the system with the wider community. Regulations are less effective if the degree of compliance only revolves around compliance (obeying for fear of being sanctioned) or identification (obeying only because of fear of good relations with someone being damaged). Conversely, if the degree of compliance reaches internalization (obedience to a rule because be truly feels that the rule is material and his spirit is in accordance with the intrinsic values adopted), it means the quality of the effectiveness of the regulation is very high, so the system runs according to the rules existing without stressing the strict control function. Of the three motives of obedience it is very likely to be the basisfor consideration of the Muslim community in Indonesia to prefer to compromise with the government or mass organizations in terms of the 
determination of the holiday.

Kata Kunci: Ketaatan, Itsbat Pemerintah, Penetapan Hari Raya

\section{A. PENDAHULUAN}

Persoalan hisab rukyat dalam hal penentuan awal bulan hijriyah-terutama bulan Ramadlan, Syawal dan Dzulhijjah-seringkali memunculkan perbedaan. Berpuluh-puluh tahun umat Islam Indonesia terjebak dalam perdebatan tiada akhir, tentang penetapan awal Ramadlan, Idul Fitri dan Idul Adha. Semakin lama bukan semakin mendekati titik temu, tetapi malah semakin menjauh. Truth claim ormas keagamaan dan belum dapat diterimanya otoritas tunggal di negeri ini menjadi pemicu adanya perbedaan yang tak berkesudahan. ${ }^{1}$

Upaya pemerintah melalui sidang itsbat pada dasarnya berpijak pada upaya tercapainya keseragaman, kemaslahatan dan persatuan umat Islam Indonesia. Pemerintah dengan berdasar pada kaidah "bukm al-hakim ilzamun wa yarfa'al-khilaf" (keputusan hakim/pemerintah itu mengikat dan menyelesaikan perbedaan pendapat). Hasil sidang isbat disampaikan kepada publik oleh Menteri Agama. Itsbat dilakukan dengan melewati berbagai pertimbangan, mulai dari data hisab dan hasil observasi (rukyat) yang merupakan hasil musyawarah Menteri Agama dengan anggota Tim Falakiah, ormas Islam dan para ahli. Disinilah keputusan sidang itsbat memiliki peran penting bagi pemerintah untuk mengakomodir perbedaan di antara ormas-ormas Islam di Indonesia dan memberikan kepastian kepada umat Islam terkait dengan penetapan awal bulan hijriyah, menjadi solusi atas perbedaan selama ini. ${ }^{2} \mathrm{Kepu}-$ tusan yang diambil pemerintah, sebagai upaya untuk mengakomodir semua madzhab semestinya dapat diterima dan diikuti oleh semua pihak. Namun dalam tataran realitas, ternyata masing-masing pihak (baca; ormas keagamaan) mengeluarkan keputusannya sendiri-sendiri.

Persoalan penetapan awal bulan Hijriah di Indonesia secara umum bersifat

${ }^{1}$ Nihayatur Rohmah, Otoritas Tunggal dalam Penetapan Awal Bulan Qamariyah: antara Harapan dan Tantangan, (Yogjakarta: Qmedia, 2016), 3. Lihat juga Nihayatur Rohmah," Otoritas dalam Penetapan Awal Bulan Qamariyah" (Konfrontasi antara Pemimpin Negara dan Pemimpin Ormas Keagamaan)" Jurnal Al-Mabsuth Vol. 9, No. 1, April 2015, ISSN: 20893427

2 Keputusan Menteri Agama Republik Indonesia Nomor 64 Tahun 2016. Tentang Pembentukan Tim Hisab Rukyat Kementerian Agama. Lihat Slamet Hambali, "Fatwa Sidang Isbat dan Penyatuan Kalender Hijriah”, (Makalah Lokakarya Internasional dan Call for Paper IAIN Walisongo Fakultas Syariah, Semarang, 12-13 Desember 2012), 8-9. 
desentralistik. Artinya, organisasi Islam masing-masing memiliki keputusan sesuai dengan metode dan kriteria yang telah ditetapkan. Seperti yang telah ditulis oleh Maskufa bahwa Semangat tajdîd yang digelorakan Muhammadiyah dalam penentuan waktu ibadah khususnya awal bulan Ramadan, Syawal dan Zulhijjah telah menjadi komitmen organisasi. ${ }^{3}$ Dalam perkembangannya, penetapan kriteria yang diikuti oleh 5 organisasi besar Nahdlatul Ulama, Muhammadiyah, Persis, Al-Irsyad dan Al-Washliyah seringkali menghasilkan kesimpulan yang berbeda. ${ }^{4}$

Mendasar pada hasil perhitungan ${ }^{5}$, rekap hasil perhitungan awal bulan Ramadlan, Syawal dan Dzulhijjah mulai tahun 2015 hingga 2025 ada beberapa titik yang berpotensi rawan adanya perbedaan. Diawali adanya perbedaan Idul adha pada tahun 2015 disebabkan karena hilal sudah wujud namun mustahil rukyah $^{6}$. Kemudian tahun 2016 hingga 2021 Indonesia berada pada zona aman, artinya umat Islam Indonesia dapat merayakan hari raya secara serentak karena posisi hilal telah memenuhi kriteria imkan rukyat ${ }^{7}$. Akan tetapi potensi adanya perbedaan hari raya di Indonesia secara berurutan akan rawan terjadi mulai tahun $2022^{8}, 2023^{9}, 2024^{10}$ dan $2025^{11}$. Adanya perbedaan tersebut disebabkan posisi bulan rendah di wilayah Indonesia. Sehingga menimbulkan hasil perhitungan yang berbeda antara pemerintah dan sejumlah organisasi massa (ormas) Islam di Indonesia.

Kemenag memiliki komitmen untuk adanya penyatuan kalender global,

3 Maskufa, Hisab Wujud Al-Hilal Sebagai Politik Identitas Muhammadiyah Dalam Diskursus Hisab Rukyat Di Indonesia, INDO-ISLAMIKA, Vol.6 No. 2 Juli-Desember 2016/1437 dalam http://journal.uinjkt.ac.id/index.php/indo-islamika/article/view/14802

${ }^{4}$ Ahmad Fadholi, Disertasi; Akseptabilitas Draf Kriteria Baru Penentuan Kalender Hijriah Oleh Ahli Falak Ormas Islam Di Indonesia, Program Doktor Studi Islam Pascasarjana, Uin Walisongo Semarang 2019

5 Winhisab version 2.0, Mawaqiit, \& Jean Meeus, juga Noor Ahmad SS, Nur al-Anwar (Kudus: Madrasah Tasywiqat Tullab Salafiyah, tt).

6 Tinggi hilal saat awal bulan Dzulhijjah adalah 0.6 dengan markaz perhitungan Pelabuhan Ratu.

7 Kriteria ImkanRukyat MABIMS minimal tinggil hilal dapat dirukyah adalah 2 derajat.

8 Tinggi hilal untuk awal bulan Dzulhijjah 1,9 (mustahil rukyah) sehingga diprediksi Muhammadiyah akan berlebaran lebih dulu dibanding dengan NU.

9 Potensi rawan berbeda pada awal bulan Syawal tinggil hilal 1,7 dan tinggi hilal untuk awal bulan Dzulhijah 0,9.

${ }^{10}$ Tinggi Hilal pada awal Ramadlan hanya 0.8 sehingga mustahil rukyat dan sangat berpotensi untuk adanya perbedaan dalam mengawali puasa Ramadlan

${ }^{11}$ Tinggi hilal awal bulan Dzulhijjah 1,4 
terbukti pada 2017 lalu Indonesia menjadi tuan rumah (seminar) fikih falakiyah Internasional. Dari hasil seminar itu diharapkan menjadi penyamaan kita termasuk kriteria, posisi dan otoritas. Namun, jika merujuk pada hasil penelitian 2006 yang lalu dikatakan bahwa Itsbat dinilai tidak efektif, karena umat Islam lebih memilih taat pada agama daripada taat pada negara dalam artian umat Islam lebih memilih mengikuti ketetapan ormas daripada itsbat pemerintah. Pilihan umat Islam ini beralasan karena masalah hari raya adalah masalah privat yang tidak bisa dilebur oleh otoritas negara apalagi negara telah menjamin kebebasan menjalankan agama sesuai dengan keyakinan masingmasing. ${ }^{12}$

\section{B. MENGOPTIK FENOMENA PENETAPAN AWAL BULAN QAMARIYAH}

Gagasan awal penulis dalam menulis artikel ini adalah dilatarbelakangi adanya keresahan sebagian besar masyarakat muslim yang menginginkan adanya persatuan umat Islam dalam merayakan hari raya. Ada baiknya melihat sejarah untuk memahami apa yang sedang terjadi sekarang dan menyusun masa depan. Mendasar pada prediksi hasil perhitungan awal bulan hijriyah bahwa dalam beberapa tahun mendatang umat Islam sangat berpotensi mengalami lebaran berbeda karena menggunakan metode yang berbeda sehingga umat Islam sangat mungkin akan merayakan hari raya tidak serentak.

Berdasarkan penelusuran penulis, ditemukan beberapa hasil penelitian, diantaranya adalah karya ilmiah yang ditulis oleh Sofwan Jannah dengan judul; Penentuan Awal Bulan Kamariyah, Permasalahan dan Upaya mengatasinya. ${ }^{13}$ Dalam karya ilmiah ini menyebutkan bahwa penerapan itsbat yang dilakukan oleh Menteri Agama RI-setelah melaksanakan sidang di Lembaga Hisab dan Rukyat merupakan usaha untuk persatuan dan kesatuan umat Islam-sejalan dengan kaidah fiqih "isbatul hakim fi masailil ijtihad yarfa'ul khilaf" Penetapan seorang hakim dalam masalah ijtihad menghilangkan persengketaan.

Berikutnya karya ilmiah yang ditulis oleh M. Nur Hidayat dengan judul "Otoritas Pemerintah Dalam Penetapan Awal Bulan Qamariyah Perspektif

${ }^{12}$ Novi Fitia Maliha, "Itsbat Pemerintah Tentang Hari Raya (Kajian terhadap Kriteria dan Efektifitasnya bagi Penyatuan Umat Islam di Indonesia)," Tesis: (Surabaya; Program Pascasarjana IAIN Sunan Ampel, 2006), 72.

${ }^{13}$ Sofwan Jannah, Penentuan Awal Bulan Kamariyah, Permasalahan dan Upaya mengatasinya dalam Proceeding Seminar Ilmu Falak 17 Januari 1994 di Planetarium dan Observatorium Jakarta. 
Figh Siyâsah Yusuf Qardhawi. ${ }^{14}$ diperoleh kesimpulan sebagaimana berikut: Pertama, Bahwa pada dasarnya pemerintah mempunyai otoritas untuk menetapkan (itsbat) awal bulan Qamariyah. Hal ini setelah melakukan analisis beberapa aspek, di-antaranya aspek pemerintahannya kemudian ruang lingkup aplikasi pendapat pemerintah, mekanisme dan keputusan pemerintah mengenai awal bulan. Oleh karena itu, pada dasarnya pemerintah mempunyai otoritas untuk menetapkan awal bulan Qamariyah. Kedua, Melihat bahwa persoalan penetapan awal bulan merupakan ranah ijitihadi, maka wajar terjadi perbedaan pendapat. Namun ketika persoalan tersebut sudah diadopsi dan ditetapkan oleh pemerintah maka menurut Qardhawi harus tetap mengikuti pemerintah. Karena pemerintah mempunyai otoritas dalam menetapkan awal bulan Qamariyah. Organisasi-organisasi diluar pemerintah hanya sekedar mempunyai hak ikhbar, meskipun demikian hendaknya organisasi-organisasi tersebut tidak boleh mendahului penetapan pemerintah. Bagi umat muslim yang tidak mempunyai kemampuan ijtihad di dalam menetukan awal bulan Qamariyah wajib mengikut kepada pemerintah dalam penetapan awal bulan Qamariyah.

. Kemudian karya ilmiah yang ditulis oleh Susiknan Azhari dengan judul;“ Fenomena Perbedan Idul Fitri Masa Orde baru; Sebuah Survei Historis ${ }^{15}$. Penelitian ini menggunakan metode survey historis yang mana berusaha mengkaji fenomena perbedaan permulaan ramadhan dan syawal. Penentuan awal bulan baru dalam kalender Hijriah merupakan suatu persoalan yang sangat penting dalam agama Islam, karena hal ini menyangkut pelaksanaan ibadah, diantaranya adalah ibadah puasa Ramadhan, yaitu dalam menentukan kapan mulai dan kapan berakhir ibadah puasa tersebut. Meskipun penetapan awal bulan baru ini merupakan persoalan yang sangat penting, namun dalam realitassnya seringkali terjadi lebaran kembar. Bahkan perbedaan itu menjadi penyebab perseteruan dan mengusik ukhuwah diantara sesama muslim.

Berikutnya adalah karya ilmiah Novi Fitia Maliha dengan Judul; "Itsbat Pemerintah tentang Hari Raya (kajian Terhadap Kriteria dan Efektifitasnya bagi Penyatuan Umat Islam di Indonesia) ${ }^{16}$. Hasil penelitian ini mengatakan

\footnotetext{
${ }^{14}$ M. Nur Hidayat dengan judul” Otoritas Pemerintah Dalam Penetapan Awal Bulan Qamariyah Perspektif Fiqh Siyâsah Yusuf Qardhawi. Jurisdictie, Jurnal Hukum dan Syariah, Volume 3, Nomor 1, Juni 2012, hlm 78-91

${ }^{15}$ Jurnal Provetika, Vol. 2 No. 1 Januari 2000

${ }^{16}$ Novi Fitia Maliha, Tesis: Itsbat Pemerintah tentang Hari Raya (Kajian Terhadap Kriteria dan Efektifitasnya Bagi Penyatuan Umat Islam di Indonesia), Surabaya: IAIN Sunan Ampel, 2006
} 
bahwa umat Islam bisa memilih yaitu mana keputusan awal bulan hijriyah lebih baik sesuai dengan keyakinannya. Dari pilihan umat tersebut pimpinan organisasi keagamaan akan berlomba-lomba untuk berijtihad yang bisa mengakomodir pilihan umat. Negara yang memasuki area privat berarti telah bersikap tidak netral, hal ini akan memicu peluang konflik karena rawan ditunggangi oleh berbagai kepentingan. Bisa saja ormas yang berusaha untuk mempengaruhi pemerintah sehingga keputusan yang diambil pemerintah sedikit banyak menguntungkan ormas tersebut sehingga timbul peluang perpecahan dengan ormas-ormas lainnya. Oleh karenanya, menurut penelitian ini dikatakan bahwa itsbat dinilai tidak efektif karena umat Islam lebih memilih taat pada agama dari pada taat pada Negara artinya umat Islam lebih memilih mengikuti ketetapan ormas daripada itsbat pemerintah.

Karya tulis Nihayatur Rohmah dengan judul; "Otoritas Dalam Penetapan Awal Bulan Qamariyah (Konfrontasi Antara Pemimpin Negara Dan Pemimpin Ormas Keagamaan). ${ }^{17}$ Problematika Hisab Rukyah senantiasa aktual untuk diperbincangkan. Kontroversi dalam penetapan awal bulan qamariyah kian menjadi tradisi yang dapat dipahami namun tetap meresahkan masyarakat. Ketika persoalan ibadah yang berdimensi social-sebagaimana persoalan penetapan dalam mengawali puasa dan mengakhiri puasa-dibutuhkanlah kerangka pemikiran yang berbasis kemaslahatan umum. Wajah bumi pertiwi kerapkali dihiasi dengan "tuntunan"yang berujung pada "tontonan" yang dapat mengancam ukhuwwah Islamiyah. Truth claim ormas keagamaan dan belum dapat diterimanya otoritas tunggal di Negeri ini menjadi pemicu adanya perbedaan yang tak berkesudahan. Ketika otoritas dikonfrontasikan antara pemimpin Negara dan pemimpin ormas maka dibutuhkanlah jiwa besar untuk mengalah guna meraih kemenangan. Jadi, berbesar hati untuk mengambil Pemerintah sebagai otoritas tunggal untuk menciptakan persatuan ummat adalah lebih utama daripada mempertahankan kriteria kalender masing-masing ormas.

Disertasi atas nama Muh. Nashirudin ${ }^{18}$ dengan judul "Kalender Hijriyah Universal, Kajian atas pemikiran M.S. Odeh dan prospeknya di Indonesia.

${ }^{17}$ Nihayatur Rohmah, "Otoritas Dalam Penetapan Awal Bulan Qamariyah (Konfrontasi Antara Pemimpin Negara Dan Pemimpin Ormas Keagamaan), Jurnal Al-Mabsut volume 9 No.1 Maret 2015, http://ejournal.iaingawi.ac.id/index.php/almabsut/article/view/17. Lihat juga Nihayatur Rohmah dengan judul; "Otoritas Tunggal dalam Pentapan Awal Bulan Qamariyah, antara Harapan dan Tantangan dalam buku Pesan Profetik Ramadlan, (Jogjakarta: Q-Media, 2016).

${ }^{18}$ Muh. Nashirudin, Disertasi "Kalender Hijriyah Universal, Kajian atas pemikiran M.S. Odeh dan prospeknya di Indonesia, (Semarang: Program Doktor IAIN Walisongo, 2012). 
Menurutnya, kalender hijriyah universal yang merupakan salah satu kalender hijriyah internasional yang diusulkan dalam berbagai seminar internasional tentang penyatuan kalender hijriyah di dunia belum begitu tersosialisasikan ke masyarakat muslim di Indonesia. Pemerintah Indonesia dalam hal ini Kementerian Agama yang diharapkan menjadi otoritas tunggal dalam menetapkan kalender hijriyah di Indonesia pun belum begitu mengikuti perkembangan pemikiran kalender hijriyah di dunia internasional. Selain itu, tidak banyak ormas Islam -salah satu elemen yang juga sangat berpengaruh terhadap penetapan awal bulan hijriyah di Indonesia - yang mewacanakan kalender hijriyah internasional dalam organisasinya. Oleh karena itu, apapun wacana tentang kalender hijriyah internasional termasuk kalender hijriyah universal sulit untuk dapat diterima di Indonesia untuk saat ini.

\section{KEPATUHAN/ KETAATAN}

Kepatuhan berasal dari kata patuh yang berarti taat, suka menurut dan disiplin terhadap perintah, aturan dan sebagainya Kepatuhan didefinisikan sebagai pemenuhan, mengalah tunduk dengan kerelaan; rela memberi, menyerah, mengalah; membuat suatu keinginan konformitas sesuai dengan harapan atau kemauan orang lain. ${ }^{19}$ Kepatuhan terkait dengan ketaatan pada otoritas aturan-aturan. kepatuhan muncul bukan karena adanya keinginan dari pelaksana perintah untuk menyesuaikan diri, tetapi lebih karena didasarkan akan kebutuhan untuk menjadi apa yang lingkungan harapkan atau reaksi yang timbul untuk merespon tuntutan lingkungan sosial yang ada. ${ }^{20}$

\section{Proses Terjadinya Kepatuhan}

Proses kepatuhan seseorang terhadap hukum disebabkan oleh beberapa faktor yaitu :

a. Penanaman kepatuhan secara sengaja (Indoctrination) yaitu sebuah peraturan hukum itu menjadi sebuah doktrin yang ditanam secara sengaja kepada masyarakat. Hal ini dilakukan agar penerapan hukum itu merata sampai keseluruh lapisan masyarakat, sehingga kepatuhan hukum yang diinginkan dapat terwujud.

\footnotetext{
${ }^{19}$ Chaplin, J.P.. Kamus Lengkap Psikologi. Terj. Kartono dan Kartini, (Jakarta: PT. Raja Grafindo Persada, 1989), 99.

${ }^{20}$ Milgram, S. 1963. "Behavioral Study of Obedience," Journal of Abnormal and Social Psychology, 67:371-378.
} 
b. Pembiasaan perilaku (Habituation) yaitu seseorang akan mematuhi peraturan hukum itu karena rutinitas yang mereka lakukan.

c. Pemanfaatan dari kaidah yang dipatuhi (Utility) yaitu seseorang mematuhi peraturan hukum itu karena dapat memanfaatkan secara substansif dari peraturan itu.

d. Mengidentifikasikan dalam kelompok tertentu (Group Indentifcation) yaitu seseorang akan mematuhi hukum ketika melihat atau mengacu pada kelompok yang telah melaksanakan.

Meskipun demikian perlu juga diperhatikan bahwa walaupun suatu norma telah disosialisasikan sedemikian rupa dan telah melembaga (institutionalized), belum tentu norma-norma itu telah benar-benar meresap (internalized) pada diri masing-masing anggota masyarakat itu. Efektifitas peraturan dalam suatu sistem organisasi juga tidak terlepas dari faktor ketaatan atau kepatuhan dari tiap anggota organisasi terhadap aturan yang ada. Maka hakikat kepatuhan hukum memiliki 3 (tiga) faktor yang menyebabkan warga masyarakat mematuhi hukum, antara lain yaitu ${ }^{21}$ :

a. Ketaatan yang bersifat compliance, yaitu jika seseorang taat terhadap suatu aturan hanya karena ia takut terkena sanksi.

b. Ketaatan yang bersifat identification, yaitu jika seseorang taat terhadap suatu aturan hanya karena takut hubungan baiknya dengan seseorang menjadi rusak.

c. Ketaatan yang bersifat internalisation, yaitu jika seseorang taat terhadap suatu aturan karena benar-benar ia merasa bahwa aturan tersebut materi dan spiritnya sesuai dengan nilai-nilai intrinsik yang dianutnya.

Kepatuhan terjadi saat orang menyesuaikan diri oleh individu kepada norma setiap kelompok yang ditemuinya, atau dimana seseorang sudah menjadi anggota atau bagian kelompok tersebut, misalnya pada saat makan di restoran internasional harus terampil dalam menggunakan sendok, garpu, dan pisau. Kepatuhan orang banyak dilakukan karena adanya tekanan dari kelompok, kepatuhan ini dilakukan untuk menghormati nilai-nilai dan etika yang berlaku di masyarakat, supaya menjaga kestabilan tatanan sosial lingkungannya. Penyesuaian diri ini dapat terjadi melalui tiga cara yaitu:

a. Konformitas perubahan perilaku secara terbuka sehingga terlihat secara umum, walaupun hatinya tidak setuju, jika perilaku menurut

${ }^{21}$ Soerjono Soekanto, Kesadaran Hukum Dan Kepatuhan Hukum, Edisi Pertama, (Jakarta: CV. Rajawali, 1982), 152 
karena perintah maka itu disebut ketaatan (Obedience) ${ }^{22}$

b. Complience yaitu perubahan perilaku atau keyakinan karena adanya tekanan dari kelompok, baik yang sungguh-sungguh ada maupun yang dibayangkan saja.

c. Penerimaaan (Acceptance) Perubahan perilaku dan kepercayaan yang sesuai dengan tatanan sosial. Selanjutnya dalam penerimaan bahwa kecenderungan untuk konform berdasarkan pengaruh yang bersifat informatif tergantung pada dua aspek, yaitu seluas apa pengetahuan kelompok tersebut, menurut individu mempercayai informasi yang dimiliki kelompok dan semakin individu menghargai pendapat kelompok tersebut pada situasi tertentu, maka semakin besar kemungkinan individu untuk konform ${ }^{23}$.

Dilihat dari adanya kepatuhan dalam komunitas, maka kita perhatikan faktor-faktor penyebab kepatuhan. (Milgram, 1963) membagi dalam beberapa faktor yang mempengaruhinya antara lain: 1. Ketaatan terhadap otoritas yang sah; yaitu dimana harapan dari orang yang menduduki posisi tertentu dalam otoritas terutama adalah yang menimbulkan ketaatan. 2. Ganjaran, hukuman, dan ancaman; yaitu: salah satu cara untuk menimbulkan ketaatan adalah dengan meningkatkan tekanan terhadap individu untuk menampilkan perilaku yang diinginkan melalui ganjaran, hukuman dan ancaman. 3 . Harapan orang lain; yaitu: seseorang rela memenuhi permintaan orang lain hanya karena orang lain tersebut mengharapkannya. 4. Teknik foot in the door, yaitu: salah satu cara untuk meningkatkan ketaatan dalam semacam ini adalah dengan membujuk orang agar mula-mula bersedia memenuhi permintaan yang ringan. 5. Batas tekanan ekternal; yaitu: cara yang langsung meningkatkan ketaatan dengan menekan individu, yang dapat dilakukan melalui ancaman, ganjaran atau tekanan sosial.

\section{TAAT PADA AGAMA DAN NEGARA DALAM PERSPEKTIF AL-QUR'AN DAN SOSIOLOGI AGAMA}

Islam, baik secara teologis, dogmatis, maupun'sosiologis, selalu hadir dalam bentuk yang tidak pernah seragam. 'Sejak wafatnya Nabi, umat Islam

${ }^{22}$ Sarwono, S. W. (1997). Psikologi Sosial Psikologi Kelompok dan Psikologi Terapan. Jakarta: Balai Pustaka.

${ }^{23}$ Sirait, M. M. (2002). Hubungan Harga Diri dengan Konformitas dalam Hal Fesyen pada Remaja. Skripsi. Depok: Fakultas Psikologi UnivE Indonesia. 
selalu dihadapkan dengan beragamnya keyakinan '('aqīdah), baik mengenai ketuhanan, kenabian, wahyu, maupun persoalan persoalan ' ghaybiyyat lainnya. Hubungan Islam dan negara tidak berhenti pada sumber nilai-nilai baru semata, Islam sebagai agama juga memiliki hubungan sosiologis dengan para penganutnya sehingga Islam bisa menjelma menjadi kekuatan politik. Islam bisa menjadi alat legitimasi politik, sehingga hubungan Islam sebagai agama dengan negara tidak bersifat tunggal dan permanen. Hubungan Islam dengan negara tidak bersifat tunggal, karena Islam telah menjelma menjadi kekuatan politik, sehingga Islam tidak lagi dipandang secara normatif yang berisi ajaranajaran semata, melainkan ajaran agama yang dianut umat manusia yang bisa berbeda-beda pandangan dan pilihan politiknya. Hubungan Islam dengan negara juga tidak permanen karena bisa mengalami pasang surut, terkadang mesra, terkadang mengalami ketegangan. ${ }^{24}$

Menurut Quraish Shihab dalam Tafsir al-Misbah bahwa surat al-Nisâ' ayat 58 dan 59 mengandung prinsip-prinsip pokok ajaran Islam dalam hal kekuasaan dan pemerintahan. Ayat 59 dari surat al-Nisâ' menyatakan adanya struktur dalam masyarakat yang disebut ûlî al-amr yang diterjemahkan sebagai orang-orang yang berwenang mengurus urusan kaum muslimin. Mereka terdiri dari para penguasa atau pemerintah, ulama, dan mereka yang mewakili masyarakat dalam berbagai kelompok dan profesinya. Dalam analisis lebih lanjut mengenai bentuk jamak pada kata $\hat{u} l i$, Quraish Shihab lebih cenderung pada pendapat yang menyatakan bahwa mereka meliputi badan atau lembaga maupun orang perorang yang masing-masing memiliki wewenang yang sah untuk memerintah dalam bidang masing-masing. ${ }^{25}$ Prinsip pokok yang diwacanakan dalam ayat tersebut menyangkut hubungan masyarakat dengan $\hat{u} l i$ al-amr adalah kepatuhan. Masyarakat wajib taat kepada para ûli al-amr suka atau tidak suka sepanjang $\hat{u} l i$ al-amr tersebut taat kepada Allah. Tidak ada ketaatan dalam durhaka atau bermaksiat kepada Allah. Menurut Quraish Shihab, taat dalam bahasa Al-Qur`an berarti tunduk, menerima secara tulus, atau menemani. Dengan demikian, ketaatan dimaksud bukan sekadar melaksanakan apa yang diperintahkan, tetapi juga ikut berpartisipasi dalam upaya yang dilakukan oleh penguasa untuk mendukung usaha-usaha pengabdian kepada masyarakat. Partisipasi masyarakat adalah dukungan positif, termasuk control sosial demi suksesnya tugas-tugas yang mereka emban.

\footnotetext{
${ }^{24}$ Anwar Mujahidin. "Konsep Hubungan Agama dan Negara Studi atas Tafsir al-Misbâh Karya M. Quraish Shihab." Dialogia: Jurnal Studi Islam 10, no. 2 (2012): 169-184.

${ }^{25}$ M. Quraish Shihab, Tafsir al-Mishbâh, Vol. 2, . 484
} 
Agama mempunyai pengaruh sebagai motivasi dalam mendorong individu untuk melakukan suatu aktifitas, karena perbuatan yang dilakukan dengan latar belakang keyakinan agama dinilai mempunyai unsur kesucian dan ketaatan. Keterkaitan ini akan memberi pengaruh seseorang untuk berbuat sesuatu. Perbuatan yang dilakukan seseorang tersebut akan terikat kepada ketentuan antara mana yang boleh dan mana yang tidak boleh menurut ajaran agama. ${ }^{26}$ Persoalan hubungan agama dan negara di masa modern merupakan salah satu subjek penting, Suatu negara diperlukan untuk mengatur kehidupan sosial secara bersama-sama dan untuk mencapai cita-cita suatu masyarakat. Di sini otoritas politik memiliki urgensinya dan harus ada yang terwakilkan dalam bentuk institusi yang disebut negara. Berdasarkan realitas tersebut, di antara kaum muslimin merasa perlu untuk merumuskan konsep negara. ${ }^{27}$

Para sosiolog teoretisi politik Islam merumuskan beberapa teori tentang hubungan agama dan negara. ${ }^{28}$ Teori-teori tersebut secara garis besar dibedakan menjadi tiga paradigma pemikiranyaitu paradigma integralistik ${ }^{29}$ (unified paradigm), paradigma simbiotik ${ }^{30}$ (symbiotic paradigm), dan paradigma sekularistik ${ }^{31}$ (secularistic paradigm). ${ }^{32}$

${ }^{26}$ Ishomudin, Pengantar Sosiologi Agama, (Jakarta: Ghalia Indonesia, 2002), 37-38.

${ }^{27}$ Kamaruzzaman, Relasi Islam dan Negara: Perspektif Modernis dan Fundamentalis, Magelang: Yayasan Indonesia Tera (Anggota IKAPI), 2011, h. V.

${ }^{28} \mathrm{Ibid}$

${ }^{29}$ Paradigma pertama menyatakan bahwa hubungan antara agama dan negara tidak dapat dipisahkan (integrated). Asumsinyaditegakkan di atas pemahaman bahwa Islam adalah satu agamasempurna yang mempunyai kelengkapan ajaran di semua segmenkehidupan manusia, termasuk di bidang praktik kenegaraan. Karenanya, umat Islam berkewajiban untuk melaksanakan sistempolitik Islami sebagaimana telah dicontohkan oleh NabiMuhammad dan empat al-Khulafa' al-Rasyidin. Pandangan ini menghendaki agar negara menjalankan dwifungsi secara bersamaan, yaitufungsi lembaga politik dan keagamaan. Din Syamsuddin, Etika dalam Membangun Masyarakat Madani, Jakarta: Logos, Jakarta, 2014, h. 58.

${ }^{30}$ Paradigma keduaberpendirian bahwa agama dan negara berhubungan secara simbiotik, antara keduanya terjalin hubungantimbal-balik atau saling memerlukan. Dalam kerangka ini, agama memerlukan negara, karena dengan dukungan negara, agama dapat berkembang. Sebaliknya negara membutuhkan agama, karena agama menyediakan seperangkat nilai dan etika untuk menuntun perjalanan kehidupan bernegara. Bahtiar Effendi, Islam dan Negara Transformasi Pemikiran dan Praktik Politik Islam di Indonesia, Jakarta: Paramadina, 2008, h. 13.

${ }^{31}$ Paradigma ketigamerefleksikan pandangan sekularistik. Menurut paradigma ini, agama dan negara merupakan dua entitas yang berbeda, sehingga tidak dapat dikaitkan secara timbalbalik. Islam dimaknai menurut pengertian Barat yang berpendapat bahwa wilayah agama sebatas mengatur hubungan individu dan Tuhan.

${ }^{32}$ Dalam Kamus Besar Bahasa Indonesia, paradigma berarti model dalam teori ilmu pengetahuan, kerangka berpikir. Depdiknas, Kamus Besar Bahasa Indonesia, Jakarta: Balai 


\section{E. DISKURSUS TENTANG BENTUK KETAATAN MASYARAKAT MUSLIM TERHADAP PENETAPAN HARI RAYA}

Penetapan hari raya di Indonesia tidak jarang mendapat sorotan dari banyak kalangan, karena pemerintah dalam hal ini yang memiliki kewenangan dalam menetapkan awal bulan hijriyah belum sepenuhnya diterima sebagai pihak yang paling otoritatif. Terdapat konfrontasi kepemimpinan antara pemerintah melalui sidang istbatnya dan pemimpin ormas keagamaan melalui maklumat maupun ikhbarnya. Tidak jarang umat Islam di Indonesia merayakan awal bulan hijriyah berbeda-beda.

Analisis Potensi perbedaan paham dikalangan umat Islam ternyata sudah diteliti oleh C. Snouck Hourgronje, seorang ilmuan ahli ketimuran (orientalis) Belanda masa penjajahan sehingga ia menyarankan diberlakukannya politik pecah kepada pemerintah Hindia Belanda. Berdasarkan rekomendasi hasil penelitian C. Snouck Hourgronje tersebut, muncullah kelompok Islam yang mau berkompromi dengan pemerintah dan kelompok Islam yang terus melawan di luar sistem bersama masyarakat luas. ${ }^{33}$ Pemikiran yang berkompromi dengan kekuasaan tidak berarti mereka lemah dan tunduk pada kekuasaan negara. Mereka memiliki sejumlah dasar semisal mendahulukan kemaslahatan umum dan mendahulukan menghindarkan kerusakan daripada memetik manfaat. Memang menentang rezim yang hegemonik, cenderung kontraproduktif, masyarakat terlibat konflik yang tidak berkesudahan. Untuk menghindari adu kekuatan antara rezim dengan masyarakat lemah, maka tidak sedikit ulama yang memilih jalan kompromi dengan kekuasaan sebagai sebuah strategi. Dengan pilihan tersebut diharapkan masyarakat bisa merasakan ketenangan dan melaksanakan ibadah sesuai tuntunan agama. Namun pilihan ini, cenderung membiarkan rezim hegemonik mempertahankan kekuasaannya dan memanfaatkan masyarakat sebagai basis legitimasinya. ${ }^{34}$

Hal ini senada dengan fenomena yang terjadi di Indonesia berkenaan dengan bentuk kepatuhan masyarakat muslim terhadap penetapan awal bulan hijriyah. Sebagian umat Islam ada yang lebih memilih untuk patuh dan taat pada keputusan pemerintah dengan berkompromi pada kekuasaan negara atas dasar pertimbangan mendahulukan asas kemaslahatan bersama dan demi

Pustaka, 2012, h. 828

${ }^{33}$ Kuntowijoyo, Identitas Politik Umat Islam (Bandung, Mizan, 1997), 197

${ }^{34}$ Anwar Mujahidin, Konsep Hubungan Agama dan Negara Studi atas Tafsir al-Misbâh Karya M. Quraish Shihab, (Ponorogo: Fakultas Ushuluddin STAIN Ponorogo, tt) 
menjaga ukhuwah Islamiyah sehingga diharapkan masyarakat akan mendapatkan ketentraman dalam beribadah. Adanya pengakuan bahwa pemerintahlah yang paling otoritatif dalam penetapan hari raya. Bentuk ketaatan semacam ini bukan tanpa alasan, namun terdapat keyakinan dari sebagian masyarakat wajib untuk taat kepada para ûli al-amr sepanjang tidak ada ketaatan dalam durhaka atau bermaksiat kepada Allah.

Selain itu, terdapat juga kelompok umat Islam yang terus melawan di luar sistem bersama masyarakat luas. Artinya sebagian masyarakat muslim lebih memilih pada keputusan pimpinan ormas keagamaan dibanding dengan keputusan pemerintah, dengan asumsi bahwa negara ini menjamin kebebasan untuk beragama. Ormas keagamaan melakukan indoctrination agar sebuah peraturan hukum itu menjadi sebuah doktrin yang ditanam secara sengaja kepada masyarakat. Hal ini dilakukan agar penerapan hukum itu merata sampai keseluruh lapisan masyarakat, sehingga kepatuhan hukum yang diinginkan dapat terwujud. Walhasil, masyarakat menjadi lebih terbiasa berperilaku (Habituation) untuk lebih memilih taat pada pimpinan ormas daripada pemerintah.

Merujuk pada teori tentang ketaatan bahwa peraturan berjalan kurang efektif bila derajat ketaatannya hanya berkisar di compliance (taat karena takut terkena sanksi) atau identification (taat hanya karena takut hubungan baiknya dengan seseorang menjadi rusak saja). Sebaliknya, bila derajat kepatuhannya mencapai internalization (taat terhadap suatu aturan karena benar-benar ia merasa bahwa aturan tersebut materi dan spiritnya sesuai dengan nilai-nilai intrinsik yang dianutnya), itu berarti kualitas efektifitas peraturan tersebut sudah sangat tinggi, sehingga sistem berjalan sesuai dengan aturan yang ada tanpa menekankan fungsi kontrol yang ketat. Dari ketiga motif ketaatan tersebut sangat mungkin menjadi dasar pertimbangan masyarakat muslim di Indonesia untuk lebih memilih berkompromi dengan pemerintah atau ormas dalam hal penetapan hari raya. 


\section{DAFTAR PUSTAKA}

Fadholi, Ahmad. "Akseptabilitas Draf Kriteria Baru Penentuan Kalender Hijriah Menurut Ahli Falak Di Indonesia." EDUGAMA: Jurnal Kependidikan Dan Sosial Keagamaan 5, no. 1 (2019): 101-114.

Hidayat, M. Nur. "Otoritas Pemerintah Dalam Penetapan Awal Bulan Qamariyah Perspektif Fiqh Siyâsah Yusuf Qardhawi." Jurisdicti: Jurnal Hukum dan Syariah 3, no. 1 (2012).

Ishomudin. Pengantar Sosiologi Agama. Jakarta: Ghalia Indonesia, 2002.

J.P., Chaplin.J.P., Kamus Lengkap Psikologi. Terj. Kartono dan Kartini. Jakarta: PT. Raja Grafindo Persada, 1989.

Jannah, Sofwan. "Penentuan Awal Bulan Kamariyah, Permasalahan dan Upaya mengatasinya." Proceeding Seminar Ilmu Falak . Jakarta: Jannah, Sofwan, Penentuan Awal Bulan Kamariyah, Permasalahan dan Upaya Planetarium dan Observatorium Jakarta, 1994.

Kamaruzzaman. Relasi Islam dan Negara: Perspektif Modernis dan Fundamentalis. Magelang: Yayasan Indonesia Tera (Angota IKAPI), 2011.

Kuntowijoyo. Identitas Politik Umat Islam. Bandung: Mizan, 1997.

Maliha, Novi Fitia. "Itsbat Pemerintah Tentang Hari Raya (Kajian terhadap Kriteria dan Efektifitasnya bagi Penyatuan Umat Islam di Indonesia." Thesis (Program Pasca Sarjana IAIN SUnan Ampel ), 2006.

Maskufa. "Hisab Wujud Al-Hilal Sebagai Politik Identitas Muhammadiyah Dalam Diskursus Hisab Rukyat Di Indonesia." Jurnal INDOISLAMIKA 6, no. 2 (2016).

Mujahidin, Anwar. "Konsep Hubungan Agama dan Negara Studi atas Tafsir al-Misbâh Karya M. Quraish Shihab." Dialogia: Jurnal Studi Islam 10, no. 2 (2012): 169-184.

Nashirudin, Muh. "Kalender Hijriyah Universal, Kajian atas pemikiran M.S. Odeh dan prospeknya di Indonesia." Disertasi (Program Doktor IAIN Walisongo), 2012.

Rohmah, Nihayatur. "Otoritas dalam Penetapan Awal Bulan Qamariyah" (Konfrontasi antara Pemimpin Negara dan Pemimpin Ormas Keagamaan)." Jurnal Al-Mabsuth 9, no. 1 (2015). 
-. Otoritas Tunggal dalam Penetapan Awal Bulan Qamariyah: antara Harapan dan Tantangan. Yogyakarta: Qmedia, 2016.

S., Milgram. "Behavioral Study of Obedience." Journal of Abnormal and Social Psychology 67 (1963): 371-378.

Sarwono, S. W. Psikologi Sosial, Psikologi Kelompok dan Psikologi Terapan. Jakarta: Balai Pustaka, 1997.

Shihab, M. Quraish. Tafsir Al-Mishbah. Cet. Ke-2. Vol. 2. Jakarta: Lentera Hati, 2009.

Sirait, M.M. "Hubungan Harga Diri dengan Konformitas dalam Hal Fesyen pada Remaja." Skripsi (Fakultas Psikologi Universitas Indonesia), 2002.

Soekanto, Soerjono. Kesadaran Hukum Dan Kepatuhan Hukum. Edisi Pertama. Jakarta: CV. Rajawali, 1982.

SS., Nur Ahmad. Nur al-Anwar. Kudus: Madrasah Tasywiqat Tullab Salafiyah, n.d.

Syamsudin, Din. Etika dalam Membangun Masyarakat Madani. Jakarta: Logos, 2014. 